\title{
Application of the IWM-PL Model for the Life Cycle Assessment (LCA) of Municipal Waste Management in Krakow. Part $1^{* *}$
}

\section{Introduction}

Life cycle assessment (LCA) is a tool for evaluating environmental aspects and potential environmental impacts, initially developed for evaluation of a product's life cycle. It is a "cradle-to-grave" approach, it enables an estimation of the environmental impacts resulting from all stages in the product life cycle from raw material acquisition through production, use, end of life treatment, recycling and final disposal [1, 2].

To performing LCA studies in a united way ISO 14040 standard [1] has been developed with four steps approach:

1. goal and scope,

2. inventory analysis,

3. impact assessment,

4. interpretation.

Goal and scope includes defining the aim and the product system boundaries and also functional unit. Life cycle inventory (LCI) is a list of extractions of raw materials used, the energy and emissions to the atmosphere, water and land related to the functional unit [3]. In the impact assessment step, the effects of the resource use and emissions generated are grouped and quantified into a limited number of impact categories such as: global warming potential (GWP), acidification, eutrophication, stratospheric ozone depletion, photo oxidant formation, resource use, land use, and others [4]. Finally the results are reported according to the goal and scope of the study in the most informative way possible.

According to Mc Dougall F. et al [5] "the life cycle of waste can be considered to be a journey from the cradle (when an item becomes valueless and, usually, is

* AGH University of Science and Technology, Faculty of Mining Surveying and Environmental Engineering, Department of Geomatics, Krakow, Poland

** The work was completed within the scope of AGH University of Science and Technology statutory research for the Department of Management and Protection of Environment no. 11.11.150.008 
placed in a dustbin) to the grave (when value is restored by creating usable material or energy); or the waste is transformed into emission to water or air, or into inert material placed in a landfill."

In other words LCA for municipal waste starts at the moment when litter is put to the waste bin and ends up when the pre-treated (mechanically, biologically or thermally) waste is disposed in the landfill. LCA assesses the use of resources and the release of emissions to air, water and land, and the generation of useful products from waste. The assessment time frame stretches from the moment when waste is generated until its final disposal takes place. LCA has become a useful tool to compare alternative waste management options, however performing LCA studies for waste management is a complex task and requires careful selection of the scope of the study as well as the assessment method in order to obtain objective and reliable results [6]. The procedure for conducting the LCA of a waste management system is very similar to the LCA of a product. The goal or objective of the study must be described, followed by the scope or systems boundaries including a definition of the functional unit, followed by the inventory or data collection for all influenced activities finalised by the impact assessment and interpretation [7].

Since the 1990s, waste LCA tools have been developed to model the environmental performance of waste management systems [8]. The models such as :

- IWM-2, UK (2001) [5];

- EPIC/CSR, Canada (1999) [9, 10];

- MSW-DST, USA (1999, 2002) [11, 12];

- ORWARE, Sweden $(1997,2002)$ [13, 14];

- WISARD, UK (1997) [15];

- WRATE, UK $(2005,2006)[16,17]$;

- EASEWASTE, Denmark (2006) [18];

- LCA-IWM, EU $(2005,2007)[19,20]$;

have been developed by a range of environmental protection agencies, universities or consultancies, mainly in Europe and North America [8].

In 2011 the first Polish language application, the IWM-PL model, was issued, which is dedicated to the evaluation of municipal waste management systems [21].

\section{Goal of the Study}

The goal of the study is the quantification of the environmental impacts from the municipal waste management system in Krakow, state in 2010, applying the IWM-PL model. The study is divided into two parts presented in two papers: Application of the IWM-PL Model for the Life Cycle Assessment (LCA) of Municipal Waste Management in Krakow. Part 1 and Application of the IWM-PL Model for the Life Cycle Assessment (LCA) of Municipal Waste Management in Krakow. Part 2 [22]. 
As the LCA approach consists of four phases:

1. goal and scope,

2. inventory analysis,

3. impact assessment,

4. interpretation,

the same structure is kept in the study. Part 1 presents goal and scope as well as inventory analysis (LCI), part 2 - life cycle impact assessment (LCIA) and interpretation. Presentation of the full study in one paper exceeds the acceptable limit for a paper for the journal.

The proper results of LCA modelling depend strongly on the exact, precise and proper data, especially in such complicated and complex systems as municipal waste management. Each developed model or software for conducting LCA analyses of a product as well as a service or a waste management system has its own structure of inputting data, requirements for scope and organization of data. After introducing the data into a model, a user of a model cannot influence the results as they are generated automatically by the model. The user can influence the results only at the stage of introducing data, so the life cycle inventory (LCI) is a core stage of a process of conducting LCA with the application of a model, for example IWM-PL model. Therefore, the goal of this paper, part 1 of the study, is the evaluation of the structure, scope and organization of the data needed by the IWM-PL model. The paper, explains thoroughly the process of gathering, estimating, calculating, assuming the data required by the IWM-PL model, in order to perform LCA of the municipal waste management system in Krakow. The uncertainties are also discussed, and data of low and high uncertainty are indicated.

\section{Methodology}

The IWM-PL model enables the quantification of the possible environmental impacts, as well as the evaluation of the economic aspects. The model requires the inputting the variety of data in 24 steps, whereof 18 steps relate to environmental aspects while the remaining steps to economic evaluation. In this study only environmental evaluation is considered. The 18 steps of introducing the data on environmental aspects are grouped into nine sections:

1) waste collection,

2) sorting,

3) refuse-derived fuel (RDF) production,

4) biological treatment,

5) thermal treatment,

6) combustion of refuse-derived fuel,

7) landfilling of non-hazardous waste,

8) landfilling of hazardous waste,

9) recycling. 
These sections together with types of required data, as well as the methods of the calculation and estimation of the needed data are explained in the main chapter of this paper, that is inventory analysis. Once the data is introduced, the IWMPl model generates a Sankey's diagram, which illustrates waste streams/fractions flows between treatment processes. The model also calculates the emissions to air and water, presented in a table. The emissions are subsequently converted into impact categories and that is presented in graphical figures. The final result of the evaluation is expressed in ecopoints in two damage categories: human health and ecosystem quality and illustrated in a graph.

The model IWM-PL requires the inputting the variety of data on the assessed waste management system. First of all, the needed data regards the quantity and morphological composition of municipal waste generated and collected in the system, and also the data on waste treatment processes, the fuel - energy balance of waste treatment installation, data on transport etc.

The sources of data on generated and collected municipal waste are available studies and reports. The municipal waste generated in Krakow have been systematically under examinations investigating the quantity of generated waste and its composition as well as other parameters [23-26]. The most recent waste analyses for Krakow municipality were performed by IETU (Institute for Ecology of Industrial Areas in Katowice) for the whole year period from November 2010 to October 2011. The scope of these analyses was: the quantity of generated waste in certain types of development structure and the balance of waste generated in Krakow, the unit generation rate of municipal waste from households and from commercial activities.

For these analyses five routes of household waste collection were selected representing three types of structure development:

1) the central part of the town - densely populated with strong a representation of commercial activity (shops, offices, banks etc),

2) multi-family houses area,

3) single-family houses area.

Besides household waste, also the municipal waste coming from city infrastructure such as: a hospital, a cemetery, a school, a hypermarket, a market place and a local administration facility was analysed [27].

The samples weighting at least $100 \mathrm{~kg}$ were taken once a month from each "route". The waste quality analyses included: sieve fractions analyses (fine fraction below $10 \mathrm{~mm}$, fraction 10-40 mm, fraction 40-100, fraction above $400 \mathrm{~mm}$ ), morphological composition of municipal waste and chemical parameters such as: water content; volatile solids in dry matter; lower heating value, heat combustion value; $\mathrm{Cl}, \mathrm{F}$, S content in dry matter; biomass content; heavy metals $(\mathrm{Zn}, \mathrm{Cd}, \mathrm{Pb}$, $\mathrm{Cu}, \mathrm{Hg}, \mathrm{Cr}$ ) content. During the morphological composition analysis waste was split into the following material fractions: organic (kitchen and garden waste), 
wood, paper, plastics, glass, textiles, metals, hazardous waste, composites, inert and others [27].

The final report on these waste analyses was issued in November 2011 [27]. The data for the model on waste quality: mixed (non-separately collected) waste composition and the composition of separately collected waste were gained from the above mentioned report [27].

The source of the data regarding the collected quantities of particular waste types in 2010 is the report on the realization of the waste management plan for years 2009-2010 [28]. Such a report, according to the law regulations, should be prepared every two years by the municipal authorities. That document is based on the reports done by all waste collector operators active in the municipality. Each operator is obliged to prepare a report every year on the quantities of collected waste types and the destinations of collected waste, that is treatment facilities. In 2010 in Krakow 82 waste collectors were present on the market of municipal waste collection and transport.

The data on the waste treatment installations, transport of waste, fuel and energy consumption were extremely difficult to obtain, as the main waste management operator in Krakow refused to deliver such data for research purposes. Therefore where necessary, assumption were made, based on own knowledge of the waste treatment processes, fragmentary information found out from the waste management operators and through the literature research. In further sections of this paper detailed justifications were given for assumptions and calculations. When obtaining the real data for processes performed in Krakow was not possible, the default values embedded into the IWM-PL model were accepted.

\section{Functional Unit and System Boundaries}

The functional unit of this LCA study is the total quantity of waste introduced into municipal waste management system in 2010 in Krakow city. The functional unit includes mixed waste, separately collected waste, bulky waste, garden waste and waste from the infrastructure (commercial sector), collected and transferred to treatment during the whole year.

The system boundaries of this analysis are defined as all processes of waste treatment performed in Krakow (recycling of secondary materials outside Krakow), transport of collected waste to the waste facilities (sorting station, dismantling station, composting plants, landfill) and also transport of secondary raw materials from the sorting station to recycling stations. The constructing of waste facilities are excluded from system boundaries, while the fuel and energy needed for operating the installations are incorporated in the system boundaries. The system boundaries are shown in Figure 1. 


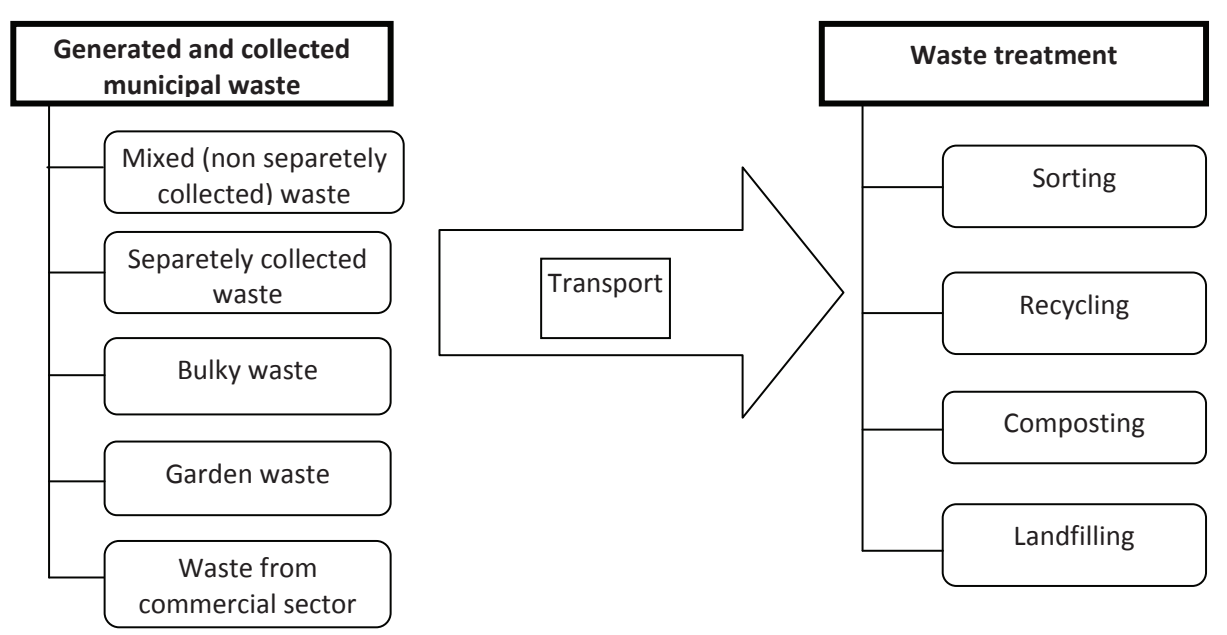

Fig. 1. System boundaries of the analysis

Source: authors' own based on [21]

\section{Inventory Analysis}

\subsection{Waste Collection}

\section{Mixed (non-separately collected) waste}

In the first step the quantity of mixed municipal waste (non-separately collected) were introduced into the model as well as its composition. The sources of data were reports $[27,28]$. The composition of metals (ferrous, non-ferrous) and plastics (hard, soft) was estimated based on [27]. The data on the quantity and morphological structure introduced into the model is shown in Table 1.

Table 1. Quantity and composition of mixed waste introduced into system

\begin{tabular}{||l|r|}
\hline Total quantity of mixed (non separated) municipal waste $[\mathrm{Mg}]$ & 255761.36 \\
\hline Waste composition [\%] & 20.48 \\
\hline Paper & 8.53 \\
\hline Glass & 2.25 \\
\hline Metals & 14.59 \\
\hline Plastics & 2.93 \\
\hline Textiles & 29.22 \\
\hline Biodegradable waste [\%] & 22.00 \\
\hline Others & \\
\hline
\end{tabular}


Table 1 cont.

\begin{tabular}{||l|r||}
\hline Compositions of metals [\%] & 70.00 \\
\hline Ferrous metals & 30.00 \\
\hline Non-ferrous metals & \\
\hline Compositions of plastics & 50.00 \\
\hline Soft plastics & 50.00 \\
\hline Hard plastics & \\
\hline
\end{tabular}

Source: authors' own based on $[27,28]$

\section{Bulky waste}

Bulky waste cannot be collected by regular vehicles dedicated to waste collection, because of the huge size. This kind of waste is mainly furniture and large electric and electronic equipment (WEEE), washing machines, refrigerators. In 2010 in Krakow $6229.86 \mathrm{Mg}$ of bulky waste was collected.

The composition of bulky waste was not examined in the recent study on the composition of municipal waste for Krakow [27]. Therefore the data on the composition of bulky waste was obtained from other sources, such as the National Waste Management Plan 2002 [29], and the Waste Management Plan for Krakow 2005 [30], which shown the data on bulky waste provided by the main municipal waste operator in Krakow - MPO. Taking into consideration these two sources the composition of bulky waste was estimated and shown in Table 2. Based on the estimation of bulky waste composition, the following quantities of bulky waste fractions were calculated and input into the model (Tab. 3). The model does not specify wood as a fraction of bulky waste, although there is the most significant fraction of this waste. Therefore the wood was assigned to the fraction "others".

Table 2. Estimated composition of bulky waste in Krakow

\begin{tabular}{|l|c|}
\hline \multicolumn{1}{|c|}{ Fraction of bulky waste } & Composition [\%] \\
\hline \hline Wood & 55 \\
\hline Ferous metals & 20 \\
\hline Non-ferrous metals & 10 \\
\hline Soft plastics & 1 \\
\hline Hard plastics & 8 \\
\hline Glass & 4 \\
\hline Others & 2 \\
\hline
\end{tabular}

Source: authors' own based on [29, 30] 
Table 3. The introduced data into the model on the bulky waste

\begin{tabular}{||l|c|}
\hline \hline Fraction of bulky waste & The quantity of fraction collected in 2010 [kg] \\
\hline Glass & 249194.40 \\
\hline Ferrous metals & 1245972.00 \\
\hline Non-ferrous metals & 622986.00 \\
\hline Soft plastics & 62298.60 \\
\hline Hard plastics & 498388.80 \\
\hline Others & 3551020.00 \\
\hline
\end{tabular}

\section{Separately collected waste}

In the third step the model requires introducing the quantity of waste separately collected to the individual containers. In 2010 in the individual IGLOO and KUBIK containers $6571.38 \mathrm{Mg}$ secondary raw materials were collected: paper: $227.27 \mathrm{Mg}$, plastics $1636.98 \mathrm{Mg}$ and glass $2707.13 \mathrm{Mg}$ [27]. Additionally, textiles were separately collected to the specific containers, the quantity of collected textiles was 1036.91 Mg in 2010 [28]. Additionally, "dry fraction" of waste mainly paper, plastics, glass, metal together was collected to yellow bags or yellow containers. The composition of dry fraction was under the examination in study [27]. Based on this report, the quantities of individual secondary raw materials: paper, plastics, glass, metal in "dry fraction" were calculated.

In Krakow garden waste is also separately collected. This waste is not gathered into containers or bins but garden waste is directly transferred by vehicles from green areas of the city to the 2 composting stations. In $201016.339 \mathrm{Mg}$ garden waste was collected and transferred to the composting plants [27].

The arrangements envisaged in the IWM-Pl model for the wastes separately collected into individual containers is that, these wastes are not sorted; they are directly transferred to the recycling installations. This arrangement is correct only for garden waste and textiles but not for the secondary raw materials. In Krakow secondary raw materials (paper, glass, plastics, metals) collected in the individual containers and the containers for "dry fractions" are transferred to the sorting station prior they are sent to recycling processes.

For the purpose of this analysis the separately collected secondary raw materials from KUBIK and IGLOO containers and yellow containers/bags for "dry fraction" were summed up together and introduced into the model as the wastes transferred to the sorting station.

The quantities of separately collected wastes sent directly to recycling plants and secondary raw materials (from KUBIK and IGLOO containers and yellow containers/bags) transferred to the sorting station were shown in Table 4. 
Table 4. Figures on the quantity of separately collected waste introduced into model

\begin{tabular}{||l|c|}
\hline \multicolumn{1}{|c|}{ Fractions directly transferred to recycling } & Quantity of fraction $[\mathrm{kg}]$ \\
\hline Textiles & 1036910.00 \\
\hline Garden waste & 16339300.00 \\
\hline \multicolumn{1}{|c|}{ Fractions transferred to the sorting station } & Quantity of fraction $[\mathrm{kg}]$ \\
\hline Paper & 6299911.90 \\
\hline Glass & 7691557.40 \\
\hline Ferrous metals & 85099.98 \\
\hline Non ferrous metals & 36471.42 \\
\hline Soft plastics & 2307739.65 \\
\hline Hard plastics & 2307739.65 \\
\hline
\end{tabular}

\section{Municipal waste from commercial sector}

Apart from waste generated in households, the system of waste management includes also municipal waste generated in city infrastructure objects such as offices, schools, universities, hospitals (excluding medical waste), shops, markets etc. The quantity of that waste was examined in the study [28] as $36456.70 \mathrm{Mg}$ in 2010. In the report [27] composition of municipal waste from commercial sector were under the examination. The composition of waste was examined for: Rydygier Hospital, Podgórski Cementary, Shopping Centre M1, market place Tomex, Town Council, elementary school no 130. Although composition of waste for these establishments is diverse, for the purpose of this analysis the composition of municipal waste from commercial sector was averaged and shown in Table 5. Those wastes are collected as mixed, not separately collected, therefore in the model the separate collection of those wastes was not introduced.

Table 5. Figures on the quantity of municipal waste from the commercial sector introduced into model

\begin{tabular}{||l|r||}
\hline Total quantity of municipal waste from commercial sector $[\mathrm{Mg}]$ & 36456.7 \\
\hline Waste composition $[\mathrm{Mg}]$ & 1.8 \\
\hline Textiles & 31.3 \\
\hline Paper & 10.0 \\
\hline Glass & 1.4 \\
\hline Metals & 19.6 \\
\hline Kitchen and garden waste & 17.3 \\
\hline Plastics & 18.6 \\
\hline Others & \\
\hline
\end{tabular}


Table 5 cont.

\begin{tabular}{||l|l||}
\hline Compositions of metals [\%] & 70.0 \\
\hline Ferrous metals & 30.0 \\
\hline Non-ferrous metals & \\
\hline Compositions of plastics [\%] & 50.0 \\
\hline Soft plastics & 50.0 \\
\hline Hard plastics & \\
\hline
\end{tabular}

\subsection{Sorting}

\section{Dismantling and sorting of bulky wastes}

In 2010 according to the report [28] $6229.85 \mathrm{Mg}$ bulky waste was collected separately, $1660.33 \mathrm{Mg}$ was recovered and $4504.47 \mathrm{Mg}$ was landfilled, that is $26.7 \%$ recovered and $72.3 \%$ landfilled. The small quantity of recovered bulky waste was due to the fact the bulky waste dismantling station started to operate in the mid of the 2010 year. In the dismantling station the bulky waste was dismantled into secondary raw materials (large WEEE) and part of bulky wastes (furniture) was processed into refuse-derived fuel (RDF). The bulky waste collected before launching the dismantling station was landfilled.

Based on [29, 30] and the previous section of this study, it was estimated that $60 \%$ of the bulky waste is furniture and approximately $40 \%$ is large electric and electronic equipment (WEEE). Furthermore it was assumed that $60 \%$ the of furniture was processed into RDF fuel. The level of raw materials recovery from large electronic and electric equipment was estimated for $70 \%$ for metals and $20 \%$ for plastics. The recovering levels of metals and plastics in relation to the total quantity of collected bulky waste are low. After the separations of raw materials (metals, plastics dedicated for recycling) the remaining waste could be either: processed into RDF fuel or landfilled.

The performed calculations indicated that $17 \%$ of the remaining bulky waste was processed into RDF fuel and $83 \%$ was landfilled. A summary of the calculations was presented in Table 6. As the IWM-PL model does not have the option of processing ballast (remaining waste) into RDF fuel, it was introduced into the model that $17 \%$ of remaining waste was thermally treated.

Another aspect concerning the dismantling and sorting of the bulky waste is transport i.e. transport of recovered materials, mainly metals, and the transport of the remaining waste (ballast). The average fuel consumption was calculated based on following assumptions: the distance to recycling plant is $30 \mathrm{~km}$ (in one way), vehicle capacity is $10 \mathrm{Mg}$, fuel consumption per $100 \mathrm{~km}$ is 35 litres, thus fuel consumption per $1 \mathrm{Mg}$ of waste (recovered materials) is 2.1 litre.

Remaining waste was transported to: landfill Barycz (83\% of remaining waste in 2010) and thermal treatment station (17\% of remaining waste in 2010$)$. The RDF fuel 
is combusted in cement kilns in the Nowiny Kielce or Częstochowa Rudniki cement plant. The distance to the Nowiny plant is $114 \mathrm{~km}$, to Rudniki $163 \mathrm{~km}$. The municipal landfill Barycz for Krakow city is located in Krzemieniecka street, $15 \mathrm{~km}$ from the bulky waste dismantling station in Nowohucka street. The data introduced into the model on dismantling and sorting of bulky wastes are shown in Table 6.

Table 6. Figures for the dismantling and sorting of bulky wastes used in the model

\begin{tabular}{|c|c|}
\hline \multicolumn{2}{|c|}{ Percentage of recovered materials from bulky wastes [\%] } \\
\hline Ferrous metals & 6.0 \\
\hline Non-ferrous metals & 1.5 \\
\hline hard plastics & 2.1 \\
\hline \multicolumn{2}{|l|}{ Transport of recovered materials } \\
\hline Average fuel consumption [litres/Mg waste] & 2.1 \\
\hline \multicolumn{2}{|c|}{ Treatment of the remaining waste (after recovery) [\%] } \\
\hline Thermal treatment & 17 \\
\hline Landfilling & 83 \\
\hline \multicolumn{2}{|l|}{ Transport of remaining waste $[\mathrm{km}]$} \\
\hline Distance to the thermal treatment station & 114 \\
\hline Distance to the landfill & 15 \\
\hline
\end{tabular}

\section{Sorting of the separately collected wastes}

The wastes collected separately in individual containers IGLOO and KUBIK as well as "dry fraction" from yellow containers and yellow bags are transported to the sorting station Barycz.

The recovery level at the Barycz sorting plant in Krakow was approximately $70 \%$ in 2010 , which means that $70 \%$ of separately collected waste after the sorting process was transferred to recycling stations (paper, plastics, glass, metal). The remaining waste called ballast was either landfilled or processed to fuel. The dismantling station for bulky waste started to operate in mid 2010, so only half at the most of the ballast could have been sent for producing RDF fuel. However, from the sorting process the finest fraction of waste, below $40 \mathrm{~mm}$, is regarded as a mineral fraction and it is always sent to landfill. The percentage of this finest fraction was assumed as $10 \%$ in the selectively collected waste. Therefore in $201055 \%$ of the ballast was sent to landfill and $45 \%$ was sent to the bulky dismantling station in order to be processed into fuel.

The Barycz landfill is very near the sorting station so the distance to landfill is $0.5 \mathrm{~km}$. The distance to thermal treatment station was calculated based on assumption that RDF fuel is sent to the Nowiny Kielce cement plant, which is $114 \mathrm{~km}$ away from Krakow. 


\section{Transport of separately collected waste to the sorting station}

The calculations made for transport of the separately collected waste to the sorting station i.e. fuel consumption, were made based on interviews with vehicles operators and literature studies [31,32]. The vehicle consumes on average 35 litres of fuel per $100 \mathrm{~km}$ when driving, additional 8 litres is used per 1 hour while loading the waste. The route of the vehicle was assumed as $20 \mathrm{~km}$ in one way, $40 \mathrm{~km}$ altogether. The loading time for separately collected waste is 15 minutes per one route. The load capacity of the vehicle transporting the separately collected waste is 5 tonnes. Then the calculated fuel consumption per one tonne of transported separately collected waste is 3.2 litre.

\section{Fuel-energy balance of the sorting station}

The operator of the sorting station refused to facilitate the data on fuel or energy consumption at the sorting station. The model IWM-Pl has default data on these aspects; the default value for energy consumption is $25 \mathrm{kWh}$ per 1 tonne of sorted waste. This value was accepted for further calculations of this study. The fuel consumption (loader, other vehicles operating) at the sorting plant was assumed as 1.5 litre per 1 tonne of the sorted waste.

Summary of calculations concerning sorting the separately collected waste is shown in Table 7.

Table 7. Figures for sorting of the separately collected wastes used in the model

\begin{tabular}{||l|c|}
\hline \multicolumn{2}{|l|}{ Transport of the separately collected waste to the sorting station } \\
\hline Average fuel consumption [litre/Mg waste] & 3.2 \\
\hline Fuel-energy balance of sorting station & 25 \\
\hline Electricity consumption [kWh/Mg waste] & 1.5 \\
\hline Fuel consumption [litre/Mg waste] & 45 \\
\hline Treatment of ballast (remaining waste after sorting) [\%] & 55 \\
\hline Thermal treatment & \\
\hline Landfilling & 114 \\
\hline Transport of remaining waste (ballast) [km] & 0.50 \\
\hline Distance to thermal treatment station & \\
\hline Distance to the landfill & \\
\hline
\end{tabular}

\section{Transport of the separately collected biowaste directly to the composting stations}

There are two composting plants in Krakow operating on the separately collected bio-waste (mainly garden waste). It was estimated that the distance in one 
way to a composting plant is $15 \mathrm{~km}$, the load capacity is $5 \mathrm{Mg}$, the fuel consumption per $100 \mathrm{~km}$ of vehicle is 30 litre (it is not a special constructed vehicle for waste transport). The fuel consumption per 1 tonne of transported bio-waste is 1.8 litre.

\subsection{Biological Treatment}

Biowaste separately collected is subject to the biological treatment-composting process, made in two composting plants: the Barycz composting plant operated by MPO and the SITA composting plant. In 2010, the number of $16339.30 \mathrm{Mg}$ biowaste was sent to composting plants. These two plants produce the high quality compost, meant for selling and used as a fertilizer. It was assumed that mass loss during the process (decomposition of organic matter) is 50\%, and $90 \%$ of the produced compost is suitable for selling. The operators of the composting plants refused to reveal the data on electricity consumption. It was assumed for $30 \mathrm{kWh}$ per 1 tonne of composting waste.

After the process all remaining waste is sent to landfilling. The Barycz composting plant is located side by side to the landfill, the distance from the SITA composting plant to Barycz landfill is $14 \mathrm{~km}$. The two composting plants work with a similar capacity. The average distance from a composting plant to the landfill was calculated as $7 \mathrm{~km}$.

The results of the calculations for the composting process are shown in Table 8.

Table 8. Figures for composting process used in the model

\begin{tabular}{|l|c||}
\hline The quantity of waste meant for composting process [Mg] & 16339.30 \\
\hline The percentage of mass loss during the process [\%] & 50 \\
\hline The quantity of produced compost [Mg] & 7965.41 \\
\hline Percentage of compost suitable for selling [\%] & 90 \\
\hline Fuel-energy balance of composting plant & 30 \\
\hline Energy consumption [kWh/Mg waste] & 0 \\
\hline Treatment of ballast (remaining waste) after composting [\%] & 100 \\
\hline Thermal treatment & \\
\hline Landfilling & 7 \\
\hline Transport of ballast after composting [km] & \multicolumn{2}{|l||}{} \\
\hline Distance to the landfill & \\
\hline
\end{tabular}

\subsection{Refuse-Derived Fuel (RDF) Production}

In the next step the model IWM-PL requires information on Refuse Derived Fuel (RDF) production from the non separately collected waste. Such a process was not realized in Krakow in 2010. 
Refused Derived Fuel has been produced in Krakow from the dismantled bulky waste as well as from the remaining waste after sorting of the separately collected waste. Such a process was described in points "Dismantling and sorting of bulky wastes" and "Thermal treatment" of this paper.

\subsection{Thermal Treatment}

For Krakow city the municipal waste thermal treatment plant is envisaged in the Waste Management Plan [33]. The thermal treatment plant is planned to start operating in 2014. In the year 2010 refuse-derived fuel (RDF) was produced and sent to combustion in cement plants. RDF has been produced from: the ballast after sorting separately collected waste, fraction bigger than $40 \mathrm{~mm}$, and wooden fraction (furniture) of the separately collected bulky waste. It was calculated that for thermal treatment in 2010 was sent $1043 \mathrm{Mg}$ of waste. In the combustion process in the cement plants, remaining waste such as ash or slag are not produced, because they are embodied into clinker [34].

This process of waste incineration was introduced into the IWM-PL model as thermal treatment. The RDF production (and combustion) process in the IWM-PL model is only envisaged for non- separately collected waste, but not for the ballast from the processing of the separately collected waste.

\subsection{Landfilling}

The majority of the municipal waste from Krakow city is landfilled, that is: mix waste (non-separately collected waste) and ballast after processing separately collected waste (apart from RDF fuel sent for combustion). The Barycz landfill is a modern, well equipped installation. Landfill gas is collected, in the gas installation, the electricity and heat is produced. Leachate is captured by the drainage system, then through the sewerage reaches the municipal wastewater treatment plant Płaszów.

Strong attempts were made to acquire the exact information on the landfilling parameters, for example fuel- energy balance, but the operator refused to provide such data.

The model IWM-Pl has some default value of landfilling parameters: heating value of landfill gas is $18 \mathrm{MJ} / \mathrm{Nm}^{3}$. The quantity of produced gas from biowaste (paper, textiles, organic matters) is $250 \mathrm{Nm}^{3} / \mathrm{Mg}$ of waste. Leachate generated from waste is $0.15 \mathrm{~m}^{3} / \mathrm{Mg}$. These values were verified against the literature studies [5, 6, 35-44] and based on that, those default values were accepted for the purpose of this study. The estimations were made for the level of recovery of landfill gas for $65 \%$, efficiency of the electricity recovery for $30 \%$.

The summary of the calculations and assumption for landfill process is shown in Table 9. 
Table 9. Figures for landfilling process

\begin{tabular}{|l|c||}
\hline \multicolumn{2}{|l||}{ Fuel-energy balance } \\
\hline Electricity consumption $[\mathrm{kWh} / \mathrm{Mg}$ waste] & 2 \\
\hline Fuel consumption (diesel oil) [kWh/Mg waste] & 1 \\
\hline Landfill gas [\%] & 65 \\
\hline Level of recovery of landfill gas & 30 \\
\hline Efficiency of electricity recovery & 75 \\
\hline Leachate & \\
\hline Efficiency of leachate treatment [\%] & \\
\hline
\end{tabular}

\subsection{Recycling}

At this step the quantities of secondary raw materials recovered at the sorting plant are calculated. The sorting station operates on the separately collected waste from the IGLOO and Kubik containers as well on the dry fraction from yellow bags and containers. The calculated quantities are shown in Table 10.

Table 10. Figures for the secondary raw materials recovered at the sorting station

\begin{tabular}{||l|c|}
\hline \multicolumn{1}{|c|}{$\begin{array}{c}\text { Secondary raw materials from } \\
\text { sorting station }\end{array}$} & $\begin{array}{c}\text { Quantities } \\
{[\mathrm{Mg}]}\end{array}$ \\
\hline \hline Paper & 4935.58 \\
\hline Glass & 6021.77 \\
\hline Ferrous metals & 131.35 \\
\hline Non-ferrous metals & 33.60 \\
\hline Soft plastics & 1808.84 \\
\hline Hard plastics & 1819.31 \\
\hline
\end{tabular}

These secondary raw materials from the sorting station are transported to the recycling plants. The contractors, to whom the sorting plant sells the secondary raw materials, are various and they fluctuate frequently, depends on the market conditions, the price for a raw material etc.

Based on the fragmentary and non-complete data given by the sorting plant operator, the purchasers of the recovered raw materials could be: Polowat, ER Max, Elanapet OLIMAR, Mobbi, Glass Works Jarosław, Glass Works Orzysz. The mentioned plants were carefully searched through existing and available open sources of information: their profile of business, including the availability of accepting the raw materials for recycling processes [45-52]. Based on the verified result of searching, the final receivers (without brokers) were identified and the distance from the sorting station in Krakow to the recycling plants were calculated. The final receivers for the 
secondary raw materials were recognised as follows: for paper - Mondi in Świecie, for glass - glass works in Jarosław, for soft plastics (foils) - Olimar plant located in Wieliczka, Marseplast in Niepołomice, for hard plastics - ERMax in Dąbrowa Górnicza and Polowat in Bielsko-Biała, for aluminium Alueco in Barczygłów (near Konin), for ferrous metals - ArcelorMittal in Krakow. The distances for the final receivers of the recovered secondary raw materials are shown in Table 11. The load capacity of the vehicle was adopted as $20 \mathrm{Mg}$.

Table 11. Figures for transport of the secondary raw materials to the recycling stations

\begin{tabular}{|l|c|}
\hline \multicolumn{1}{|c|}{ The secondary raw material } & $\begin{array}{c}\text { Distance to the recycling stations } \\
{[\mathrm{km}]}\end{array}$ \\
\hline \hline Paper & 480 \\
\hline Glass & 215 \\
\hline Ferrous metals & 15 \\
\hline Non-ferrous metals & 380 \\
\hline Soft plastics & 15 \\
\hline Hard plastics & 85 \\
\hline Textiles & 15 \\
\hline
\end{tabular}

\section{Discussion of the results of the life cycle inventory}

The above mentioned results of the life cycle inventory can be divided into two categories:

1) the life inventory results with low uncertainty,

2) the life inventory results with high uncertainty.

The results with low uncertainty are these related to the quantity of the collected waste introduced into the system (mix waste and separately collected waste) and the composition of non-separately collected waste. The uncertainty of data on the quantity of the collected waste depends on the quality of the elaborated report on the realization waste management plan [28]. That document in turn is based on the reports prepared by the waste collector operators and depends strongly on their reliability and credibility.

The uncertainty with the composition of non-separately collected waste relates to the variability of the generated waste (season, type of built-up area, society's affluence etc.). It could be assumed that examination on the composition of municipal waste in Krakow was properly conducted by IETU [27]. IETU is one of the leading centres in Poland performing such examinations. But still the variability of the waste composition is significant through the years and proven by the multiple researches conducted for the same city [23-27]. Moreover the composition of bulky waste for this study was calculated based on available literature studies [29, 30]. 
Even though data on the quantity and composition of waste introduced into the system have some limitations, the uncertainty of results of the life inventory in this scope is low, contrary to the uncertainty of the inventory of the treatment processes, transport and sorting, which is high. For each process assumptions and calculations were made because of the lack the exact data. Particulate difficult was the proper estimation of the waste transport parameters in various stages, and fuel - energy balances of the waste treatment plants.

The values for transport introduced into the model were estimated and calculated as averages. Yet, the routes of waste transport are exceedingly diverse, load capacities of different vehicle types are various as well as fuel consumption per $100 \mathrm{~km}$. The default values of the IWM-Pl model accepted for the purpose of this study, energy consumption or fuel consumption of the waste treatment plants are burdened with some uncertainty. Other parameters of the waste treatment processes are not either absolutely certain. For example default value for gas generated from $1 \mathrm{Mg}$ organic fraction of waste is $250 \mathrm{~m}^{3} / \mathrm{Mg}$ in the IWM-PL model. While according to various authors, those values could range from $180-240 \mathrm{~m}^{3} / \mathrm{Mg}$ of mix waste [37], 120-180 $\mathrm{m}^{3} / \mathrm{Mg}$ mix waste [35], $150-170 \mathrm{~m}^{3} / \mathrm{Mg}$ mix waste [39].

Additionally the structure of introducing the data in the IWM-PL model has some limitation. For example the production process of the RDF fuel is possible only for non-separately collected waste, but not for remaining waste (ballast) after sorting of the separately collected waste and dismantling of the bulky waste.

The life cycle inventory results are the subject for the next phase of the life cycle assessment - the life cycle impact assessment LCIA. The results of LCIA are shown in the part 2 of the study.

\section{References}

[1] EN ISO 14040:2006: Environmental management - Life cycle assessment principles and framework. CEN European Committee for Standardization, Brussels 2006.

[2] Life Cycle Assessment: Principles and Practice. U.S. Environmental Protection Agency (EPA), EPA/600/R-06/060, May 2006.

[3] Life Cycle Approaches - the Road from Analysis to Practice. UNEP/SETAC Life Cycle Initiative, United Nations Environment Programme. Division of Technology, Industry and Economics, Paris, France 2005.

[4] Pennington D., Potting J., Finnveden G., Lindeijer E., Jolliet O., Rydberg T., Rebitzer G.: Life cycle assessment Part 2: Current impact assessment practice. Environment International, vol. 30, 2004, pp. 721-739. 
[5] McDougall F, White P, Franke M, Hindle P.: Integrated solid waste management: a life cycle inventory. $2^{\text {nd }}$ ed. Blackwell Publishing, Oxford 2001.

[6] Den Boer E., Den Boer J., Jager J., Rodrigo J. (Eds): Waste management planning and optimisation. Handbook for municipal waste prognosis and sustainability assessment of waste management systems. Ibidem-Verlag, Stuttgart 2005.

[7] Kirkeby J.: Modelling of life cycle assessment of solid waste management systems and technologies. Institute of Environment \& Resources, Technical University of Denmark, March 2005 [Ph.D. thesis].

[8] Gentil E.C., Damgaard A., Hauschild M., Finnveden G., Eriksson O., Thorneloe S., Kaplan P.O., Barlaz M., Muller O., Matsui Y., Ryota Ii, Christensen T.H.: Models for waste life cycle assessment: Review of technical Assumption. Waste Management, vol. 30, 2010, pp. 2636-2648.

[9] Haight M.: EPIC/CSR Integrated Solid Waste Management Model. Final Report., Canada, 1999.

[10] Haight M.: Integrated Solid Waste Management Model. Technical Report. University of Waterloo, School of Planning, Waterloo, Canada, 2004.

[11] Weitz K.A., Barlaz M.A., Ranjithan S., Brill E.D., Thorneloe S.A., Ham R.: Life cycle management of municipal solid waste. International Journal of Life Cycle Assessment, vol. 4(4), 1999, pp. 195-201.

[12] Solano E., Ranjithan S.R., Barlaz M.A., Brill E.D.: Life-cycle-based solid waste management. I: Model development. Journal of Environmental Engineering, vol. 128, 2002, pp. 981-992.

[13] Dalemo M., Sonesson U., Björklund A., Mingarini K., Frostell B., Jönsson H., Nybrant T., Sundqvist J.O., Thyselius L.: ORWARE - a simulation model for organic waste handling systems. Part 1: Model description. Resources, Conservation and Recycling, vol. 21, 1997, pp. 17-37.

[14] Eriksson O., Frostell B., Björklund A., Assefa G., Sundqvist J.-O., Granath J., Carlsson M., Baky A., Thyselius L.: ORWARE - a simulation tool for waste management. Resources, Conservation and Recycling, vol. 36, 2002, pp. 287-307.

[15] Ecobilan. Life Cycle Research Programme for Waste Management: Inventory Development for Waste Management Operations: Landfill, Final Report. Environment Agency, Bristol, UK, 1997.

[16] Gentil E., Hall D., Thomas B., Shiels S., Collins M.: LCA tool in waste management: new features and functionalities. Proceedings of Sardinia $2005,10^{\text {th }}$ International Landfill Symposium, Cagliari, CISA publisher, 2005.

[17] Coleman T.: Life Cycle Assessment for Municipal Waste: Supporting Decisions. Resources Recovery Forum. Annual General Meeting, July 19, London, UK, 2006. 
[18] Kirkeby J.T., Birgisdottir H., Hansen T.L., Christensen T.H., Bhander G.S., Hauschild M.Z.: Environmental assessment of solid waste systems and technologies: EASEWASTE. Waste Management and Research, vol. 24(1), 2006, pp. 3-15.

[19] Den Boer E., Den Boer J., Jager J., Rodrigo J., Meneses M., Castells F., Schanne L.: Deliverable Report on D3.1 and D3.2: Environmental Sustainability Criteria and Indicators for Waste Management (Work Package 3). The Use of Life Cycle Assessment Tool for the Development of Integrated Waste Management Strategies for Cities and Regions with Rapid Growing Economies LCA-IWM. Darmstadt, Germany, 2005.

[20] Den Boer E., Den Boer J., Jager J.: LCA-IWM: a decision support tool for sustainability assessment of waste management systems. Waste Management, vol. 27, 2007, pp. 1032-1045.

[21] Kraszewski A., Pietrzyk-Sokulska E. (red.): Ocena systemu gospodarki odpadami. Wydawnictwo Instytutu Gospodarki Surowcami Mineralnymi i Energią Polskiej Akademii Nauk, Kraków 2011.

[22] Grzesik K.: Application of the IWM-PL Model for the Life Cycle Assessment (LCA) of Municipal Waste Management in Krakow. Part 2. Geomatics and Environmental Engineering, vol. 7, no. 4, 2013, pp. 43-58.

[23] Terakowski M. et. al. Badania ilości struktury odpadów komunalnych Miasta Krakowa. Raport końcowy. Instytut Ekologii Terenów Uprzemysłowionych, Katowice, sierpień 1995.

[24] Maksymowicz B. et al.: Badania ilości i struktury odpadów komunalnych miasta Krakowa. Raport końcowy. OBREM Ośrodek Badawczo-Rozwojowy Ekologii Miast, Łódź, październik 2000.

[25] Roszko K., Chełkowski M.: Badania ilości, składu morfologicznego i właściwości odpadów komunalnych statych powstających w Krakowie. Conseko, Kraków, marzec 2003.

[26] Sieja L.: Badanie ilości i struktury odpadów komunalnych Miasta Krakowa. Raport końcowy. Instytut Ekologii Terenów Uprzemysłowionych, Katowice, czerwiec 2008.

[27] Sieja L. et al.: Badanie ilości i struktury odpadów komunalnych Miasta Krakowa. Raport końcowy. Instytut Ekologii Terenów Uprzemysłowionych, Katowice, listopad 2011.

[28] Dalman J., Muszyński K., Polek A.: Sprawozdanie z realizacji „Planu Gospodarki Odpadami dla Miasta Krakowa - plan na lata 2008-2011 oraz perspektywa na lata 2012-2015" za okres sprawozdawczy: od 01.01.2009 do 31.12.2010 r. Urząd Miasta Krakowa, Kraków, czerwiec 2011.

[29] Uchwała Nr 219 Rady Ministrów z dnia 29 października 2002 r. w sprawie krajowego planu gospodarki odpadami. M.P. 2003, nr 11, poz. 159.

[30] Grabowski Z., Sacharczuk J., Kalinowska E. et al.: Plan gospodarki odpadami dla miasta krakowa: plan na lata 2005-2007 z uwzględnieniem zadań zrealizowanych w 2004 roku oraz perspektywa na lata 2008-2011. Kraków 2005. 
[31] Departament Środowiska Urzędu Marszałkowskiego Województwa Kujawsko-Pomorskiego: Aspekty ekonomiczne organizacji selektywnej zbiórki odpadów w gminie. Konferencja "Zasady prowadzenia selektywnej zbiórki odpadów w gminie", Przysiek k. Torunia, 17 maja 2012, [on-line:] http:// www.kujawsko-pomorskie.pl/index.php?option=com_content\&task=vie w\&id=21462\&Itemid=117 [access: September 2012].

[32] Walny M.: Problemy z ustalaniem stawek opłat. Przegląd Komunalny, nr 3, 2009, pp. 55-57.

[33] Baic I., Karuga S., Witkowska-Kita B., Ostatkiewicz A.: Plan gospodarki odpadami dla miasta Krakowa: plan na lata 2008-2011 oraz perspektywa na lata 2012-2015. Załącznik do uchwały Nr LXXVIII/999/09 Rady Miasta Krakowa z dnia 1 lipca 2009 r.

[34] European Commission: Reference Document on Best Available Techniques in the Cement, Lime and Magnesium Oxide Manufacturing Industries. May 2010.

[35] Stegmann R.: Ergebnisse von Abbauversuchen im Laborversuch, Gas und Wasserhaushalt von Mulldeponien, Veröffentlichungen des Instituts für Stadtbauwesen, TU Braunschweig, Heft 33, 1982.

[36] TabasaranO.,RettenbergerR.:GrundlagenzurPlanungvonEntgasungsanlagen. [in:] Müll-Handbuch, Band 4, Erich Schmidt Verlag, Berlin 1987.

[37] Ehrig, H.-J.: Untersuchungen zur Gasbildung aus Hausmull. [in:] MüllHandbuch, Band 4, Erich Schmidt Verlag, Berlin 1986.

[38] Leikam K., Stegmann R.: Stellenwert der mechanisch-biologischen Restabfallbehandlung. Abfallwirtschaftsjournal, 9, 1996, pp. 39-44.

[39] Tabasaran O., Rettenberger R.: Möglichkeiten zur Ermittlung des Gaspotenzials. BMFT, Umweltbundesamt: Deponiegasnutzung 1984.

[40] Heyer K.-U., Stegmann R.: Leachate management: leachate generation, collection, treatment and costs. 2001, [on-line:] http://www.ifas-hamburg.de/pdf/ leachate.pdf [access: September 2012].

[41] Schwing E.: Bewertung der Emissionen der Kombination mechanisch-biologischer und thermischer Abfallbehandlungsverfahren in Südhessen. Institut WAR, TUD Darmstadt, WAR-Schriftenreihe Bd. 111, Darmstadt 1999 [dissertation].

[42] Fudala-Książek S.: Wpływ zrzutu odcieków składowiskowych na efektywność pracy miejskiej oczyszczalni ścieków. Politechnika Gdańska, Gdańsk 2011 [Ph.D. thesis].

[43] Szpadt R.: Wysypiska odpadów komunalnych, charakterystyka odcieków. Biuletyn Informacyjny. Budownictwo. Gospodarka Miejska, vol. 4, 1988, pp. 72-76.

[44] Szpadt R.: Usuwanie i oczyszczanie odcieków ze składowisk odpadów komunalnych. Przegląd Komunalny, nr 12(183), 2006, pp. 60-66. 
[45] Concern I-O Owens IIlinois, [on-line:] http://www.o-i.pl/ [access: September 2012].

[46] Polowat enterprise, [on-line:] http://www.polowat.pl/ [access: September 2012].

[47] Ermax enterprise, [on-line:] http://www.ermax.com.pl/index.php?a=ofirmie [access: September 2012].

[48] Mondi enterprise in Świecie, [on-line:] http://www.mondigroup.pl/strona. aspx? $a=304 \& \operatorname{lng}=1045$ [access: September 2012].

[49] Alueco enterprise, [on-line:] http://www.alueco.com/pl/ekologia-i-rynkowosc [access: September 2012].

[50] Elenapet enterprise, [on-line:] http://www.elanapet.pl/pl/recykling-pet [access: September 2012].

[51] Olimarenterprise,[on-line:]http://www.olimar.pl/main.swf[accessSeptember 2012].

[52] Marseplast enterprise, [on-line:] http://www.marseplast.com/ [access: September 2012]. 